\title{
Has Collective Management of Copyright Run Its Course? Not so Fast
}

\author{
Sylvie Nérisson
}

Published online: 23 July 2015

(C) Max Planck Institute for Innovation and Competition, Munich 2015

Fifteen years ago, voices predicted the end of collective management of copyrights. The main reason was that technical protection measures made the individual control for right holders over their works as ubiquitous as copyrighted works and subject matters themselves. This end did not come - and it probably won't - rather the exact contrary.

"Authors' societies" appeared in France as a private initiative of playwrights in order to enforce their authors' rights against the monopoly of the Parisian theatre. Collective management organizations (CMOs) then developed in the western countries on a private basis, following the increase in copyrighted uses and the growth of mass-uses of copyrighted works made possible by new technologies. In the second half of the twentieth century, legislators took over. As authors' and neighbouring rights were no longer considered only as exclusive or as property rights, but also as a way to remunerate statutorily permitted uses, copyright laws anchored the activities of CMOs in the authors' and neighbouring rights landscape. The German Copyright Act (Urheberrechtsgesetz) of 1965, published together with the Copyright Administration Act (Urheberrechtswahrnehmungsgesetz) is the first example of this move.

The successive references to collective management in the EU copyright directives reveal first its virtues: the rental and lending rights directive recommends collective management as a tool that ensures that the remuneration effectively reaches creators and performers; the satellite and cable directive made collective management mandatory in order to ease the clearing of exclusive rights, for the sake of an undisturbed retransmission of broadcastings. Then the flaw in collective management is revealed: the directive on copyright in the information society recalls in a discrete but severe recital 17 that: "It is necessary, especially in the light

\section{S. Nérisson $(\square)$}

Ph.D., Paris I University (France) and Humboldt University in Berlin (Germany); Senior Research Fellow, Max Planck Institute for Innovation and Competition, Munich, Germany

e-mail: sylvie.nerisson@ip.mpg.de 
of the requirements arising out of the digital environment, to ensure that collecting societies achieve a higher level of rationalisation and transparency with regard to compliance with competition rules." And finally, for now, the European Union in 2014 released a directive "on collective management of copyright and related rights and multi-territorial licensing of rights in musical works for online use in the internal market", the longest of the EU directives dealing with copyright law, which therein reveals the other flaw in the topic: that it is extremely complicated. Most provisions of this directive are to be implemented by April 2016 in the 28 Member States.

This implementation, however, is not the only reason for the growing interest in the topic. Still in Europe, at least two questions raised in preliminary rulings currently pending before the European Court of Justice are decisive for the regulation of CMOs, respectively for the way CMOs have solved slippery issues of copyright law.

Firstly, the Belgian case Reprobel v. Hewlett Packard (Case No. C-572/13) asks whether and how publishers are to benefit from private copy fees (see the third question); although, they are not mentioned as right holders in Directive 2001/29. This question is crucial to most CMOs dealing with authors' rights in music and writing, since they mostly represent authors and publishers together and distribute fees to both groups according to lump share keys.

The French highest administrative court delivered the other upcoming preliminary ruling whose outcome will be crucial for the collective management landscape (Conseil d'État, decision of 6 May 2015, Case No. 368208). The French law of 1 March 2012 boldly re-invented the Google-Books-style opt-out in order to foster the digitization and commercial distribution of out-of-print books that are still protected by copyright. Books published in France in the twentieth century, and no longer available on the first-sale market, are registered in a database held by the national library. If neither the creator nor the publisher opt out, the law vests the management of the digital rights of the registered books in a collecting society whose board is composed half by authors half by publishers. A reaction against this law was not to be expected from the publishers' side: the legislator pampered them with this law. But some writers considered this new scheme as an expropriation of their rights and filed an action against the decree implementing this law. After the Constitutional Court rejected a challenge to the constitutionality of this law, the highest administrative court now awaits an answer from the ECJ (Case No. C-301/15) regarding the following question: do Arts. 2 and 5 of Directive 2001/29/EU (the articles granting the reproduction right, listing the limitations and exceptions to exclusive rights and implementing the three-step test into EU law) hinder that legal provisions of Member States (like the French provisions regarding the digital publication of out-of-print books of the twentieth century) entrust authorized CMOs with the exercise of the right to reproduce out-of-print books in digital form, considering that authors and right holders of these books may oppose or end the collective management scheme at any moment in the conditions defined by the relevant provisions?

Both questions emphasize the role collective management plays in striking a balance in the relation between industry on the one hand and creators on the other 
hand, but also between the narrow realm for statutorily permitted uses on the one hand and the public's call for easy access to works on the other hand. Digital rights management as such cannot help to do so.

These questions, and above all the need for clearing agencies fairly representing the interests of all stakeholders, are acute not only in the EU, but in all countries where copyright law struggles in adapting to new technologies. Also, here and there and beyond the European landscape, the digital dilemma leads, for example, to discussions of bills introducing technology-neutral extensions of mandatory licenses for broadcasting or retransmitting per cable, involving CMOs for commercial users to have a chance to respect copyright law without excessive transaction costs, and for creators and artists to have a chance to receive their share of the pie.

It would therefore be wise that the collective management of authors' and neighbouring rights is no longer a specialists' niche, occupied by scholars dealing with the intersection of copyright and competition law (due to the natural monopoly of CMOs), and with remuneration and/or secondary rights, which are by far no longer residual. It would be wise as well for all copyright players and scholars to lift the veil of the scapegoat or sacred cow that still covers CMOs. The implementation process of Directive 2014/26/EU should therefore retain the attention of all. The collective management of copyright is much too serious a matter to be left to parliaments, lobbies and executive boards of stakeholders. 